\title{
Türkçe Öğretmeni Adaylarının Akademik Okuryazarlık Düzeyleri ile Teknoloji Yeterliği Öz-Değerlendirmeleri Arasındaki İlişki
}

\author{
Yusuf Mete Elkırana, b
}

\section{Özet}

$\mathrm{Bu}$ araştırmada Türkçe öğretmeni adaylarının akademik okuryazarlık düzeyleri ile teknoloji yeterliği öz-değerlendirmeleri arasındaki ilişkiyi belirlemek amaçlanmıştır. Bu kapsamda Türkiye'nin batısındaki bir devlet üniversitesinin Türkçe öğretmenliği programındaki 171 öğretmen adayının yanıtları toplanmıştır. Araştırmada veri toplama aracı olarak "Akademik Okuryazarlık Ölçeği” ve "21. Yüzyıl Öğrenmelerinde Teknoloji Yeterliliği Öz-değerlendirme Ölçeği" kullanılmıştır. Analizler doğrultusunda Türkçe eğitimi öğretmen adaylarının akademik okuryazarlık düzeyleri ile teknoloji yeterliği özdeğerlendirmelerinin yüksek düzeyde olduğu sonucuna ulaşılmıştır. Cinsiyet değişkenine göre erkek katılımcıların akademik okuryazarlık düzeyleri daha yüksektir. Cinsiyet değişkenine göre teknoloji yeterliğinde anlamlı fark göstermediği sonucuna ulaşılmıştır. Sınıf düzeyi değişkenine göre akademik okuryazarlık düzeyleri ile teknoloji yeterliği öz-değerlendirmelerinde anlamlı fark göstermediği sonucuna ulaşılmıştır. Akademik başarı düzeyi değişkenine göre akademik okuryazarlık düzeylerinde ve teknoloji yeterliğinde anlamlı fark görülmüştür. Türkçe öğretmeni adaylarının akademik okuryazarlık düzeyleri ile teknoloji yeterliği öz-değerlendirmeleri arasında orta düzeyde, pozitif ve anlamlı bir ilişki olduğu sonucuna ulaşılmıştır.
Anahtar Kelimeler

Akademik Okuryazarlık

Teknoloji Yeterliği

Türkçe Eğitimi

Makale Hakkında

Geliş Tarihi: 27.07.2021

Kabul Tarihi: 24.09.2021

Doi: 10.18026/cbayarsos. 975296

\section{The Relationship Between Prospective Turkish Teachers Academic Literacy and Technology Proficiency Self-Assessments}

\begin{abstract}
The aim of this study is to examine the relationship between prospective Turkish teachers' academic literacy and technology proficiency selfassessment. In this context, the opinions of 171 pre-service teachers from different grade levels of Pre-Service Turkish Language Teachers of a state university in the west of Turkey were consulted. The relational screening method, which is one of the quantitative research methods, was used. According to the analyzes, it was concluded that the academic literacy levels of the participants and their self-evaluation of technology proficiency were at a high level. Significant differences were investigated with the variables of gender, class level and academic standing. It was concluded that there is a moderate, positive and significant relationship between the academic literacy levels of prospective Turkish teachers' and their self-evaluation of technology proficiency.
\end{abstract}

Keywords

Academic Literacy

Technology Proficiency

Turkish Education

About Article

Received: 27.07.2021

Accepted: 24.09.2021

Doi: 10.18026/cbayarsos.975296

a İletişim Yazarı: ymelkiran@gmail.com

b Öğr. Gör. Dr., Çanakkale Onsekiz Mart Üniversitesi, Eğitim Fakültesi, Bilgisayar ve Öğretim Teknolojileri Eğitimi Bölümü, ORCID ID.https://orcid.org/ 0000-0001-8372-8555. 


\section{Giriş}

Okur, okuma özelliğine sahip olan kimse olarak tanımlanabilirken yazar ise yazma özelliği olan kimse olarak tanımlanmıştır. Okuryazar kavramı Türk Dil Kurumu (TDK) sözlüğünde okuma ve yazma özelliği olan kimse olarak tanımlanmaktadır (TDK, 2021). 1947 yılında kurulmuş olan Birleşmiş Milletler Eğitim, Bilim ve Kültür Kurumu (UNESCO) ise başlarda bu tanıma yakın bir politika güderek okuma, yazma ve cebirsel işlemlerin öğretilmesini teşvik etmek amacıyla ilköğretimin yaygınlaştırılması üzerine devletleri yönlendirirken günümüzdeyse sürekli değişen ve gelişen dijital dünyada bilgiyi anlama, yorumlama, eser oluşturma ve yayma gibi iletişim temelli bir çok beceriyi kapsayan bir kavram olarak okuryazarlığı geleneksel, işlevsel, bilinçlendirici, çoklu ve çeşitli okuryazarlıklar kapsamlarında dünya çapında desteklemektedir (Güneş, 2019; UNESCO, 1968, 2021). UNESCO gelecekle ilgili stratejisinde okuryazarlıkların gelişimi ve sürdürülebilir öğrenmeleri iyileştirmek için dijital teknolojilerden yararlanma, okuryazar ortamlar geliştirme, öğretimde çocukluktan başlayarak güçlü temeller oluşturmaya yönelik yaklaşımlar benimsemektedir. Birleşmiş Milletler'in (UN) aldığı kararla UNESCO tüm dünyada sürdürülebilir kalkınmayı destekleyerek yoksulluğu azaltarak çocuk ve aile sağlığı ile beslenmeyi geliştirerek yaşam olanakları sunmanın itici gücü olarak okuryazarlıkları desteklemeye yönelik çalışmaları sürdürmektedir (UN, 2015).

Akademik okuryazarlık kavramı, çoklu ve çeşitli okuryazarlıklar kapsamında değerlendirilebilir. Çünkü okuryazarlığın tek tipten kültürle, dille, koşul ve durumlara göre genişlediği ve çeşitlendiği yaklaşımlar mevcuttur (Akkaya ve Toprak, 2020; Güneş, 2019). Akademik okuryazarlığın temel harcındaysa bilim ve gerçeklik vardır. Bilim, sözlükte “Evrenin veya olayların bir bölümünü konu olarak seçen, deneye dayanan yöntemler ve gerçeklikten yararlanarak sonuç çıkarmaya çalışan düzenli bilgi, ilim." olarak tanımlanmıştır (TDK, 2021). Bilim, bilimsel yayınlar, bilimsel bilginin ulaşılması, anlaşılması, üretilmesi, yayılması ile gerçeğe ve hayata uyarlanabilmesi konuları akademik okuryazarlığın ana öğelerini oluşturmaktadır. Akademik okuryazarlık; geçmiş ve taze bilgiye ulaşma, onları analiz etme, değerlendirme, yeniden üreterek güncelliğini koruyabilme becerisi olarak değerlendirilebilir (Branscomb, 1981; Doru, 2018; Elmborg, 2006; Kurudayığlu ve Çimen, 2020; Miller 1983). Bilimsel bilgiyi anlayabilmek için ana dilini iyi kullanmak ve iyi bir iletişim kurmak gerekir. Bu nedenle anlama (okuma, dinleme ve izleme) ve anlatma (konuşma ve yazma) dil becerilerine hakim olmak oldukça önemlidir. İletişimde kanal öğesi olarak değerlendirebilen yazı, yüzyıllardır dünya milletleri tarafından değişik şekillerde kullanılırken günümüzde ise zamanla dijital ortamlarda ses şekilleri ile biçimsel öğelerle beraber anlaşılabilir hale gelmiştir (Karatay, 2011). Dil becerilerinin gelişimiyse Türkçe öğretmenlerinin donanımına, öğretim heyecanına, içsel ve dışsal motivasyonlarına, kullanılan öğretim yöntem ile tekniklere ve kişinin dil yatkınlıkları gibi her biri çok önemli olan farklı değişkenlere bağlıdır. Bu değişkenler Türkçe öğretmenlerinin üzerine önemli bir sorumluluk yüklemektedir.

Her çağın kendine özgü yenilikleri olduğu gibi 21. yüzyılda da yönlendirici olan yeni teknolojiler mevcuttur ve bu yeni teknolojiler insanlar arası iletişimin gelişimini farklılaştırmıştır. Toplum yaşamında dijitalin yüksek dönüşümünü içten içe yaşıyoruz ve bu dönüşüme kayıtsız kalmak fırsatlardan uzak kalmak olarak yorumlanabilir. Yeni kitle iletişim araçları toplum tarafından kolaylaştırıcı niteliklerinden dolayı hızlıca benimsenmiştir (Güneş, 2016). İnternetin yaygınlaşması ile yazılı ve basılı medya dijital ortamlara taşınmış ve yeni 
medya araçları tarafından taranıp daha hızlı ulaşılabilir hale gelmiştir. Kitapların ve kütüphanelerin mekan bağımlılığı sınırlaması zamanla zayıflamaya başlamıştır. Teknolojiyi kullanma becerisi ve dijital yatkınlık sadece öğretmenin değil yaşamın içinde aktif olan her bireyin mecburiyeti haline gelmiştir. Dijital vatandaşlığın yaygınlaştığı̆, devletin dijital uygulamaların kullanarak bireylerin zamandan ve ekonomiden tasarruf yapabildiği mobil teknolojiler hayatın her alanına yayılmıştır (Arcagök, 2020; Ustabulut, 2021). Bu yeni medya araç ve platformlarının teorik olarak nasıl oluştuğu, sorunlarla karşılaşınca nasıl çözüm üretilebileceği, var olan bilgiye nasıl ulaşılabileceği, sınıfın dijital yetkinliğinin farkına varıp öğrenme materyallerini nasıl uyarlayabileceği gibi bilgiler ve yetkinliklerle donanmış öğretmenlere ihtiyaç doğmuştur. Yenilenen toplum ve iletişimler dil becerilerinin önemini her geçen gün arttırırken bu yöndeki ihtiyaçları karşılamak amacıyla Cumhuriyetin ilk yıllarından günümüze Türkçe öğretim programları da geleceği yakalamak amacıyla güncelleştirilmeye çalışılmıştır (Güneş, 2016; Güzel ve Karadağ, 2013, Özbay ve Özdemir, 2014; Temizyürek ve Balcı, 2015). Bu öğretim programlarına bağlı olarak öğretmen yetiştirme kurumları da bu bağlamda kendini güncellemiş ve teknolojik araçlara aşina, ders materyallerinde entegrasyon yönünden çă̆1 yakalayabilmiş Türkçe öğretmenleri yetiştirmiştir (Baş ve Yıldırım, 2018; Elkıran, 2017; Geçgel, Kana, Öztürk ve Akkaş, 2020). Ayrıca Türkiye'de 21. yüzyılın ilk çeyreğinde devletin uygulamaya koyduğu Fırsatları Artırma ve Teknolojiyi İyileştirme Hareketi Projesi kapsamında Eğitim Bilişim Ağı, Milli Eğitim Bakanlığı Bilişim Sistemleri, Eokul gibi çalışmalar doğrudan dijital araçlarla öğrenci, veli, okul ve bakanlık organları arasında anlık bilgi erişimini sağlayan ve öğrenme öğretme ortamlarını zenginleştirip kolaylıklar sunan sistemlerdir. Öğretmenler mesleğe atandıktan sonra hem özlükleri hem kurum hem de öğrencilerle ilgili birçok iş ve işlemleri bu sanal platformlarda yapmaktadırlar. Böylelikle öğretmenler için de teknoloji araçlarının kullanımı vazgeçilmez bir gereksinim olmuştur.

Öğreticilerin kendilerini akademik olarak donanımlı hale getirmek için çağın ihtiyaçlarına göre akademik okuryazarlık becerilerini meslekleri ile bütünleştirmeleri ve anadili öğretiminde öğrenenlere sunmaları beklenmektedir. Dil becerilerinin de okuryazarlıklar gibi bilişim teknolojileri ile beraber güncel olarak yorumlanma ihtiyacı oluşmuştur. Dijital altyapılara hakim olarak derse hazır gelerek, olası teknik aksaklıklarda çözümleyici olarak öğrenenlere bilgiye nasıl ulaşacaklarını, nasıl analiz edecek ve nasıl benzer ürünler haline getirebileceklerini öğretip onların yeni teknolojilerde akademik okuryazarlıklarını geliştirebilmeleri beklenmektedir.

$\mathrm{Bu}$ bağlamda Türkçe öğretmen adaylarının akademik okuryazarlık düzeyleri ile teknoloji yeterliği öz-değerlendirmeleri arasındaki ilişkinin ortaya konulması amaçlanmıştır. Böylelikle öğretmen adaylarının akademik okuryazarlıkları ile dijital dünyadaki durumları hakkında bilgi edinilmesi düşünülmektedir. Bu amaca yönelik olarak aşağıda araştırma problem cümleleri sunulmuştur:

a. Katılımcıların teknoloji yeterliği öz-değerlendirmeleri ne düzeydedir?

b. Katılımcıların akademik okuryazarlıkları ne düzeydedir?

c. Katılımcıların akademik okuryazarlıkları cinsiyet, sınıf ve akademik başarı değişkenlerine göre anlamlı bir farklılık göstermekte midir?

d. Katılımcıların teknoloji yeterliği öz-değerlendirmeleri cinsiyet, sınıf ve akademik başarı değişkenlerine göre anlamlı bir farklılık göstermekte midir? 
Türkçe Öğretmeni Adaylarının Akademik Okuryazarlık Düzeyleri ile Teknoloji Yeterliği Öz-Değerlendirmeleri Arasındaki İlişki

e. Katılımcıların akademik okuryazarlık düzeyleri ile teknoloji yeterliği özdeğerlendirmeleri arasında bir ilişki var mı?

\section{Yöntem}

\section{Araştırma Modeli}

Bu araştırmada, Türkçe öğretmeni adaylarının akademik okuryazarlık düzeyleri ile teknoloji yeterliği öz-değerlendirmeleri arasındaki ilişkiyi incelemek için nicel araştırma yöntemlerinden ilişkisel tarama modeli kullanılmıştır. Tarama araştırması, belirli bir sınıfın algılanan niteliklerini anlamlandırabilmek için verilerin toplandığ $\breve{1}_{1}$ araştırmalardır (Büyüköztürk, Kılıç Çakmak, Akgün, Karadeniz ve Demirel, 2018). Bu araştırmada Türkçe öğretmeni adaylarının dijital yazma tutumları ile dijital okuma eğilimleri, veri toplama aracında yer alan değişkenler arası ilişkiler incelenmiştir. İki ve daha çok sayıdaki değişkenin birarada değişim varlığı veya derecesi İlişkisel tarama modellerinde belirlenmeye çalışılmaktadır (Karasar, 2007).

\section{Örneklem Grubu}

Araştırmanın örneklem grubunu, Çanakkale Onsekiz Mart Üniversitesi Türkçe Eğitimi Ana Bilim Dalında öğrenim gören 171 Türkçe öğretmeni adayı oluşturmaktadır. Araştırmanın örneklem grubuna dair tanımlayıcı istatistik analizleri verilmiştir.

Tablo 1. Araştırmaya Katılanların Cinsiyetleri

\begin{tabular}{ccc}
\hline Cinsiyet & $\mathbf{f}$ & $\mathbf{\%}$ \\
\hline Kadın & 135 & 78.9 \\
Erkek & 36 & 21.1 \\
\hline
\end{tabular}

Tablo 1'de görüldüğ ü üzere araştırmanın katılımcılarının \%78.9'unun kadın, \% 21.1'inin erkek olduğu görülmektedir.

Tablo 2. Araştırmaya Katılanların Sınıf Düzeyleri

\begin{tabular}{ccc}
\hline Sinif & $\mathbf{f}$ & $\mathbf{\%}$ \\
\hline 1. Sinif & 32 & 18.7 \\
2. Sinif & 35 & 20.5 \\
3. Sinif & 45 & 26.3 \\
4. Sinif & 59 & 34.5 \\
\hline
\end{tabular}

Tablo 2' de görüldüğgü üzere araştırmaya katılanların \%18.7'sinin birinci sınıf, \%20.5' inin ikinci sınıf, \%26.3'ünün üçüncü sınıf, \%34.5'inin ise dördüncü sınıf olduğu görülmektedir.

Tablo 3. Araştırmaya Katılanların Akademik Başarı Ortalamaları

\begin{tabular}{ccc}
\hline Not Ortalamaları & $\mathbf{f}$ & $\%$ \\
\hline 0-2,5 Puan & 15 & 8.8 \\
$2,51-3,00$ Puan & 53 & 31.0 \\
$3,01-4,00$ Puan & 103 & 60.2 \\
\hline
\end{tabular}


Tablo 3'te görüldüğü üzere araştırmaya katılanların \%8.8'inin 0-2.5 puan, \%31.0'ının 2.51-3.00 puan arası ve \%60.2'sinin 3.01-4.0 puan arası not ortalamasına sahip olduğu görülmektedir.

Tablo 4. Araştırmaya Katılanların Günlük Ortalama İnternette Geçirdikleri Süre

\begin{tabular}{ccc}
\hline Süre & $\mathbf{f}$ & \% \\
\hline 0-1 Saat & 10 & 5.8 \\
2-3 Saat & 49 & 28.7 \\
4-6 Saat & 92 & 53.8 \\
7 Saat ve Üzeri & 20 & 11.7 \\
\hline
\end{tabular}

Tablo 4'te görüldüğü üzere araştırmaya katılanların bir günde ortalama \%5.8'inin 0-1 saat, \%28.7'sinin 2-3 saat, \%53.8'inin 4-6 saat, \%11.7'sinin ise yedi veya yediden fazla saat süresince internette zaman geçirdikleri görülmektedir.

\section{Veri Toplama Araçları}

Kişisel Bilgi Formu, araştırmacı tarafından oluşturulmuş olup ölçeklerden önce öğretmen adaylarına sunulmuştur. Kişisel bilgi formu ile katılımcıların cinsiyet, sınıf, akademik başarı düzeyi ve internette bir günde geçirdikleri süre verilerinin toplanması amaçlanmıştır.

Demir ve Deniz (2020) tarafından geliştirilen beşli likert tipi ölçek olan “Akademik Okuryazarlık Ölçeği” kullanılmıştır. Geliştirilen ölçek bir ile beş arasında likert türünde puanlamayı gerektirmektedir. Üç boyuttan oluşan ölçeğin madde sayısı 23'tür. Üç adet (17., 18. ve 20.) ters madde mevcuttur. Ölçme aracı, "Akademik Eğilim", "Araştırma Süreci" ve "Bilgi Kullanımı" olmak üzere üç alt boyuttan oluşmaktadır. Genel olarak tüm öğretmenler için tasarlanmış olsa da ölçme aracının geliştirilmesi Türkçe öğretmeni adayları ile hazırlanmıştır. Elde edilen puanlar 1-1.80 puan arası "kesinlikle katılmıyorum" ile, 1.81-2.60 puan aralığ "katılmıyorum", 2.61-3.40 puan aralığ 1 "kararsızım" veya "orta derecede katılıyorum" ile, 3.41-4.20 puan aralığı "katılıyorum" ve 4.21-5.00 puan aralığ1 "kesinlikle katılıyorum" düzeyinde değerlendirilmektedir. Bu araştırmada Akademik Okuryazarlık Ölçeğgi'nin CronbachAlfa iç tutarlılık katsayısı 936 olarak hesaplanmıştır.

Christensen ve Knezek'in geliştirdiği (2017) “21. Yüzyıl Öğrenmelerinde Teknoloji Yeterliliği Özdeğerlendirme Ölçeği" Fidan, Debbağ ve Çukurbaşı (2020) tarafından Türk kültürüne uyarlanmış beşli likert tipi bir ölçme aracı kullanılmıştır. Uyarlanan ölçek bir ile beş arasında likert türünde puanlamayı gerektirmektedir. Ölçek yeterlik, zorluk, adanmışlık ve kaçınma olmak üzere dört boyuttan oluşmaktadır. Ölçme aracında ters puanlanan madde bulunmamaktadır. Ölçeğin madde sayısı 24 madden oluşan ölçek "www", "E-posta”, "Entegre Uygulamalar" ve "Teknolojiyle Öğretim" olmak üzere dört alt boyuta sahiptir . Elde edilen puanlar 1-1.80 puan arası "kesinlikle katılmıyorum" ile, 1.81-2.60 puan aralığı "katılmiyorum", 2.61-3.40 puan aralığ 1 "kararsızım" veya "orta derecede katılıyorum" ile, 3.41-4.20 puan aralığı "katılıyorum" ve 4.21-5.00 puan aralığ1 "kesinlikle katılıyorum" düzeyinde değerlendirilmektedir. Bu araştırmada 21. Yüzyıl Öğrenmelerinde Teknoloji Yeterliliği Öz-değerlendirme Ölçeği'nin Cronbach-Alfa iç tutarlılık katsayısı .706 olarak hesaplanmıştır..

Verilerin Analizi 
Araştırmada aritmetik ortalama ( $\bar{X})$ ile standart sapma (Ss) değerlerine veri analizi programlarından IBM firmasının ürettiği SPSS programı ile ulaşılmıştır. Araştırmanın basıklık ve çarpıklık değerleri -2 ile +2 puanları arasında olduğu sonuçlarına ulaşılmıştır. Bu sonuçlarla normalliği sağlayan puan aralığı eşleşmektedir (George ve Mallery, 2010). Çarpıklık ve basıklık puanları normal dağılım puan aralığında olduğu için çalışmada analizler için tek yönlü ANOVA, t-testi ve pearson korelasyon analizleri uygulanmıştır.

\section{Etik Kurul İzni}

Araştırmada uygulanan ölçekler kullanılmadan önce ölçekleri uyarlayan araştırmacılardan eposta yoluyla kullanım izni alınmıştır. Araştırma bir Eğitim Fakültesi'nde öğrenim gören öğretmen adaylarıyla gerçekleştiği için bu Eğitim Fakültesi'nden ölçeklerin uygulanmasıyla ilgili resmi olarak yazı ile izin alınmıştır. Çanakkale Onsekiz Mart Üniversitesi Sosyal Bilimler ve Eğitim Bilimleri Etik Kurulu 04.12.2020 tarih, 06/45 sayılı kararı ile araştırmanın bilimsel etik kurallara uygun olduğu kararı verilmiştir.

\section{Bulgular}

Tablo 5. Katılımcıların Akademik Okuryazarlıklarının Analiz Sonuçları

\begin{tabular}{lccc}
\hline Boyutlar ve Ölçek & $\mathbf{N}$ & $\overline{\mathbf{X}}$ & $\mathbf{S}$ \\
\hline Akademik Eğilim Boyutu & 171 & 4.69 & .32 \\
Araştırma Süreci Boyutu & 171 & 4.60 & .50 \\
Bilgi Kullanımı Boyutu & 171 & 4.65 & .40 \\
Akademik Okuryazarlık & 171 & 4.65 & .36 \\
\hline
\end{tabular}

Tablo 5'te görüldüğü üzere, katılımcıların Akademik Okuryazarlık Ölçeği'ne verdikleri yanıtların ortalama beş üzerinden $\bar{X}=4.65$ ile yüksek düzeyde olduğu ve "Kesinlikle Katılıyorum" şeklinde yanıtladıkları görülmektedir. Bununla beraber Akademik Okuryazarlık Ölçeği'nin "Akademik Eğilim" alt boyutuna yüksek düzeyde ( $\bar{X}=4.69$ ), "Araştırma Süreci" alt boyutuna yüksek düzeyde $\bar{X}=4.60$ ve "Bilgi Kullanımı" alt boyutuna yüksek düzeyde $(\overline{\mathrm{X}}=4.65)$ yantt verdikleri görülmektedir.

Tablo 6. Katılımcıların 21. Yüzyıl Öğrenmelerinde Teknoloji Yeterliliği Öz-

Değerlendirmelerinin Analiz Sonuçları

\begin{tabular}{lccc}
\hline Boyutlar ve Ölçek & $\mathbf{N}$ & $\overline{\mathbf{X}}$ & $\mathbf{S}$ \\
\hline www Boyutu & 171 & 4.87 & .22 \\
E-posta Boyutu & 171 & 4.86 & .26 \\
Entegre Uygulamalar Boyutu & 171 & 3.79 & .74 \\
Teknolojiyle Öğretim Boyutu & 171 & 4.60 & .34 \\
21. Yüzyıl Öğrenmelerinde & 171 & 4.57 & .25 \\
Teknoloji Yeterliliği Öz- & & & \\
değerlendirme & & & \\
\hline
\end{tabular}


Tablo 6'da görüldüğü üzere, katılımcıların 21. Yüzyıl Öğrenmelerinde Teknoloji Yeterliliği Öz-değerlendirme Ölçeği'ne verdikleri yantların ortalama beş üzerinden $\bar{X}=4.57$ ile yüksek düzeyde olduğu ve "Kesinlikle Katılıyorum" şeklinde yanıtladıkları görülmektedir. Bununla beraber 21. Yüzyıl Öğrenmelerinde Teknoloji Yeterliliği Öz-değerlendirme Ölçeği'nin “www” alt boyutunda ( $\overline{\mathrm{X}}=4.87)$, "E-posta" alt boyutunda $(\overline{\mathrm{X}}=4.86)$ ve "Entegre Uygulamalar" alt boyutunda $(\bar{X}=3.79)$ ve "teknolojiyle öğretim" alt boyutunda $(\bar{X}=4.60)$ 21. yüzyıl öğrenmelerinde teknoloji yeterliliği öz-değerlendirme algılarının yüksek düzeyde olduğu görülmektedir.

Tablo 7. Ölçeklere Ait Basıklık ve Çarpıklık Değerleri

\begin{tabular}{lcc}
\hline Boyut & Çarpıklık & Basıklık \\
\hline Akademik Eğilim Boyutu & -1.006 & .209 \\
Araştırma Süreci Boyutu & -1.007 & -.245 \\
Bilgi Kullanımı Boyutu & -1.245 & .940 \\
Akademik Okuryazarlık & -928 & .171 \\
www Boyutu & -1.130 & .566 \\
E-posta Boyutu & -1.073 & .256 \\
Entegre Uygulamalar Boyutu & .136 & -1.335 \\
Teknolojiyle Öğretim Boyutu & -.796 & .424 \\
21. Yüzyıl Öğrenmelerinde & -.470 & .264 \\
Teknoloji Yeterliliği Öz-değerlendirme & & \\
\hline
\end{tabular}

Tablo 7'de görüldüğü üzere Akademik Okuryazarlık Ölçeği'nin tamamının (Çarpıklık: -.928, Basıklık: .171), 21. Yüzyıl Öğrenmelerinde Teknoloji Yeterliliği Öz-değerlendirme Ölçeği'nin tamamının (Çarpıklık: -.470, Basıklık: .264), Akademik Eğilim alt boyutunun (Çarpıklık: -1.006, Basıklık: .209), Araştırma Süreci alt boyutunun (Çarpıklık: -1.007, Basıklık: -.245), Bilgi Kullanımı alt boyutunun (Çarpıklık: -1.245, Basıklık: .940), www alt boyutunun (Çarpıklık: 1.130, Basıklık: .566), E-posta alt boyutunun (Çarpıklık: -1.130, Basıklık: .566), Entegre Uygulamalar alt boyutunun (Çarpıklık: -1.130, Basıklık: .566) ve Teknolojiyle Öğretim alt boyutunun (Çarpıklık: -1.130, Basıklık: .566) değerlerinin -2 ile +2 arasında değer aldığ sonucuna ulaşılmıştır. Bu çerçevede ölçekler ve alt boyutlardan elde edilen verilerin -2 ile +2 arasında değer alması dikkate alındığında bu araştırmada analizler için parametrik (normal dağılım gösteren) testler uygulanmıştır.

Katılımcıların akademik okuryazarlık düzeyleri ile teknoloji yeterliği öz-değerlendirmelerinin cinsiyet değişkenine göre farklılık durumunu anlamak için bağımsız gruplar $t$ testi uygulanmış ve sonuçlar Tablo 8 ve Tablo 9'da görülmektedir. 
Türkçe Öğretmeni Adaylarının Akademik Okuryazarlık Düzeyleri ile Teknoloji Yeterliği Öz-Değerlendirmeleri Arasındaki İlişki

Tablo 8. Katılımcların Akademik Okuryazarlık Düzeylerinin Cinsiyet Değişkenine Göre Analiz Sonuçları

\begin{tabular}{llllllll}
\hline Boyut & Cinsiyet & $\mathbf{N}$ & $\overline{\mathbf{X}}$ & Ss & Sd & $\mathbf{t}$ & $\mathbf{p}$ \\
\hline Akademik Eğilim & Kadın & 135 & 4.66 & .33 & 169 & -2.13 & .03 \\
& Erkek & 36 & 4.79 & .25 & & & \\
Araştırma Süreci & Kadın & 135 & 4.57 & .51 & 169 & -1.64 & .10 \\
& Erkek & 36 & 7.72 & .44 & & & \\
Bilgi Kullanımı & Kadın & 135 & 4.61 & .41 & 169 & -2.67 & .00 \\
& Erkek & 36 & 4.81 & .28 & & & \\
Toplam & Kadın & 135 & 4.62 & .37 & 169 & -2.20 & .02 \\
& Erkek & 36 & 4.77 & .29 & & & \\
\hline
\end{tabular}

Tablo 8'de görüldüğü üzere Türkçe öğretmeni adaylarının Akademik Okuryazarlık ölçeğinin bütünü dikkate alındığında cinsiyet değişkeni açısından ölçeğin bütününde anlamlı bir fark göstermektedir $\left(t_{(169)}=-2.20, p<\right.$.05). Başka bir ifadeyle erkek katılımcıların akademik okuryazarlık düzeyi ( $\overline{\mathrm{X}}=4.77)$ kadın katılımcıların akademik okuryazarlık düzeylerine $(\overline{\mathrm{X}}=4.62)$ göre daha yüksek düzeydedir. Akademik Eğilim alt boyutunda cinsiyet değişkeni açısından erkek katılımcıların lehine $(\overline{\mathrm{X}}=4.79)$ anlamlı bir fark göstermektedir $\left(\mathrm{t}_{(169)}=-2.13, \mathrm{p}<.05\right)$. Bilgi kullanımı alt boyutunda cinsiyet değişkeni açısından erkek katılımcıların lehine $(\bar{X}=4.81)$ anlamlı bir fark göstermektedir $\left(\mathbf{t}_{(169)}=-2.67, \mathrm{p}<.05\right)$. Ayrıca Araştırma Süreci alt boyutunda cinsiyet değişkeni açısından anlamlı bir fark göstermemektedir $\left(\mathrm{t}_{(169)}=-1.64, \mathrm{p}>.05\right)$.

Tablo 9. Katılımcıların Teknoloji Yeterliği Öz-Değerlendirmelerinin Cinsiyet Değişkenine

Göre Analiz Sonuçları

\begin{tabular}{llllllll}
\hline Boyut & Cinsiyet & $\mathbf{N}$ & $\overline{\mathbf{X}}$ & $\mathbf{S s}$ & $\mathbf{S d}$ & $\mathbf{t}$ & $\mathbf{p}$ \\
\hline E-posta & Kadın & 135 & 4.83 & .28 & 169 & -2.44 & .00 \\
& Erkek & 36 & 4.98 & .07 & & & \\
Kadın & 135 & 4.84 & .24 & 169 & -2.28 & .00 \\
& Erkek & 36 & 4.97 & .08 & & & \\
Entegre Uygulamalar & Kadın & 135 & 3.86 & .74 & 169 & 2.64 & .00 \\
& Erkek & 36 & 3.50 & .65 & & & \\
Teknolojiyle Öğretim & Kadın & 135 & 4.58 & .36 & 169 & -1.42 & .15 \\
& Erkek & 36 & 4.66 & .26 & & & \\
Toplam & Kadın & 135 & 4.57 & .27 & 169 & -.74 & .45 \\
& Erkek & 36 & 4.60 & .18 & & & \\
\hline
\end{tabular}

Tablo 9'da görüldüğü üzere Türkçe öğretmeni adaylarının 21. Yüzyıl Öğrenmelerinde Teknoloji Yeterliliği Öz-değerlendirme ölçeğinin bütünü dikkate alındığında cinsiyet 
değişkeni açısından anlamlı bir fark göstermemektedir $\left(\mathrm{t}_{(169)}=-2.20, \mathrm{p}>.05\right)$. E-posta alt boyutunda cinsiyet değişkeni açısından erkek katılımcıların lehine $(\overline{\mathrm{X}}=4.98)$ anlamlı bir fark göstermektedir $\left(\mathrm{t}_{(169)}=-2.44, \mathrm{p}<.05\right)$. www alt boyutunda cinsiyet değişkeni açısından erkek katılımcıların lehine $(\bar{X}=4.97)$ anlamlı bir fark göstermektedir $\left(t_{(169)}=-2.28, p<.05\right)$. Entegre uygulamalar alt boyutunda cinsiyet değişkeni açısından kadın katılımcıların lehine $(\bar{X}=3.86)$ anlamlı bir fark göstermektedir $\left(\mathrm{t}_{(169)}=2.64, \mathrm{p}<.05\right)$. Ayrıca teknolojiyle öğretim alt boyutunda cinsiyet değişkeni açısından anlamlı bir fark göstermemektedir $\left(\mathrm{t}_{(169)}=-1.42, \mathrm{p}>.05\right)$.

Sınıf düzeyi değişkeni açısından ölçeğin bütünü ve alt boyutları dikkate alındığında Türkçe öğretmeni adaylarının akademik okuryazarlıklarına yönelik algı düzeylerinin farklılaşıp farklılaşmadığını belirlemek amacıyla Tek yönlü ANOVA testi uygulanmıştır. Uygulanan testler sonucunda elde edilen sonuçlar Tablo 10' de gösterilmiştir.

Tablo 10. Katılımcıların Akademik Okuryazarlık Düzeylerinin Sınıf Düzeyi Değişkenine Göre Tek Yönlü Anova Analiz Sonuçları

\begin{tabular}{llllllll}
\hline & $\begin{array}{l}\text { Varyansın } \\
\text { Kaynağı }\end{array}$ & $\begin{array}{l}\text { Kareler } \\
\text { Toplamı }\end{array}$ & sd & $\begin{array}{l}\text { Kareler } \\
\text { Ortalaması }\end{array}$ & F & p & $\begin{array}{l}\text { Anlamlı } \\
\text { Fark }\end{array}$ \\
\hline Akademik Eğilim & Gruplararası & .569 & 3 & .190 & 1.835 & .143 & - \\
& Gruplariçi & 17.268 & 167 & .103 & & & \\
& Toplam & 17.837 & 170 & & & & \\
Araştırma Süreci & Gruplararası & 1.676 & 3 & .559 & 2.271 & .082 & - \\
& Gruplariçi & 41.084 & 167 & .246 & & & \\
& Toplam & 42.760 & 170 & & & & \\
Bilgi Kullanımı & Gruplararası & .607 & 3 & .202 & \multirow{2}{*}{1.262} & .289 & - \\
& Gruplariçi & 26.771 & 167 & .160 & & & \\
& Toplam & 27.378 & 170 & & & & \\
& Gruplararası & .832 & 3 & .277 & 2.112 & .101 & - \\
& Gruplariçi & 21.941 & 167 & .131 & & & \\
& Toplam & 22.774 & 170 & & & & \\
\hline
\end{tabular}

Tablo 10'da görüldüğü üzere Türkçe öğretmeni adaylarının akademik okuryazarlıklarının sınıf düzeyi değişkenine göre anlamlı farklılık göstermemektedir $\left[\mathrm{F}_{(3-167)}=2.112 ; \mathrm{p}>.05\right]$. Bununla beraber akademik eğilim $\left[\mathrm{F}_{(3-167)}=1.835 ; \mathrm{p}>\right.$.05], araştırma süreci $\left[\mathrm{F}_{(3-167)}=2.271 ; \mathrm{p}>\right.$.05] ve bilgi kullanımı $\left[\mathrm{F}_{(3-167)}=1.262 ; \mathrm{p}>\right.$.05] alt boyutlarında da sınıf düzeyi değişkenine göre anlamlı bir farklılık göstermemektedir.

Sınıf düzeyi değişkeni açısından ölçeğin bütünü dikkate alındığında Türkçe öğretmeni adaylarının teknoloji yeterliliği öz-değerlendirmelerinin farklılaşıp farklılaşmadığını belirlemek amacıyla Tek yönlü ANOVA testi uygulanmıştır. Uygulanan testler sonucunda elde edilen sonuçlar Tablo 11' de gösterilmiştir. 
Türkçe Öğretmeni Adaylarının Akademik Okuryazarlık Düzeyleri ile Teknoloji Yeterliği Öz-Değerlendirmeleri Arasındaki İlişki

Tablo 11. Katılımcıların Teknoloji Yeterliliği Öz-değerlendirmelerinin Sınıf Değişkenine Göre Tek Yönlü Anova Analiz Sonuçları

\begin{tabular}{llllllll}
\hline & $\begin{array}{l}\text { Varyansın } \\
\text { Kaynağı }\end{array}$ & $\begin{array}{l}\text { Kareler } \\
\text { Toplamı }\end{array}$ & sd & $\begin{array}{l}\text { Kareler } \\
\text { Ortalaması }\end{array}$ & F & p & $\begin{array}{c}\text { Anlamlı } \\
\text { Fark }\end{array}$ \\
\hline E-posta & Gruplararası & .510 & 3 & .170 & 2.546 & .058 & \\
& Gruplariçi & 11.156 & 167 & .067 & & & \\
& Toplam & 11.666 & 170 & & & & \\
www & Gruplararası & .100 & 3 & .033 & .644 & .587 & \\
& Gruplariçi & 8.622 & 167 & .052 & & & \\
& Toplam & 8.722 & 170 & & & & \\
Entegre Uygulamalar & Gruplararası & 6.883 & 3 & 2.294 & 4.410 & $.005^{*}$ & A-D \\
& Gruplariçi & 86.872 & 167 & .520 & & & \\
& Toplam & 93.755 & 170 & & & & \\
Teknolojiyle Öğretim & Gruplararası & .197 & 3 & .066 & .538 & .687 & \\
& Gruplariçi & 20.411 & 167 & .122 & & & \\
& Toplam & 20.609 & 170 & & & & \\
& Gruplararası & .183 & 3 & .061 & .924 & .431 & \\
& Gruplariçi & 11.017 & 167 & .066 & & & \\
& Toplam & 11.200 & 170 & & & & \\
\hline
\end{tabular}

$\mathrm{p}^{*}<.05$, A:1.Sinif, B:2. Sinif, C:3. Sinif, D:4. Sinif

Tablo 11'de görüldüğü üzere Türkçe öğretmeni adaylarının teknoloji yeterliliği özdeğerlendirmelerinin sınıf düzeyi değişkenine göre ölçeğin bütününde [ $\left.\mathrm{F}_{(3-167)}=.924, \mathrm{p}>.05\right]$, eposta $\left[\mathrm{F}_{(3-167)}=2.546, \mathrm{p}>.05\right]$, www alt boyutunda $\left[\mathrm{F}_{(3-167)}=.644, \mathrm{p}>.05\right]$ ve Teknolojiyle öğretim alt boyutunda $\left[\mathrm{F}_{(3-167)}=.538, \mathrm{p}>.05\right]$ anlamlı bir fark göstermemektedir. Teknolojiyle Öğgretim alt boyutunda ise anlamlı fark görülmüştür. Bu farkın hangi gruplar arasında kaynaklandığını ortaya çıarmak amacıyla Tukey testi yapılmıştır. Tukey testine göre entegre uygulamalar alt boyutunda $\left[\mathrm{F}_{(3-167)}=4.410 ; \mathrm{p}<.05\right], 4$. Sinif $(\overline{\mathrm{X}}=4.03)$ katılımcların lehine 1. sinif $(\overline{\mathrm{X}}=3.50)$ katılımcılara göre anlamlı bir fark görülmüştür.

Akademik başarı düzeyi değişkeni açısından ölçeğin bütünü ve alt boyutları dikkate alındığında Türkçe öğretmeni adaylarının akademik okuryazarlıklarına yönelik alg1 düzeylerinin farklılaşıp farklılaşmadığını belirlemek amacıyla Tek yönlü ANOVA testi uygulanmıştır. Uygulanan testler sonucunda elde edilen sonuçlar Tablo 12' de gösterilmiştir. 
Tablo 12. Katılımcıların Akademik Okuryazarlık Düzeylerinin Akademik Başarı Düzeyi

Değişkenine Göre Tek Yönlü Anova Analiz Sonuçları

\begin{tabular}{clllllll}
\hline & $\begin{array}{l}\text { Varyansın } \\
\text { Kaynağı }\end{array}$ & $\begin{array}{l}\text { Kareler } \\
\text { Toplamı }\end{array}$ & $\begin{array}{l}\text { sd } \\
\text { Akademik Eğilim }\end{array}$ & $\begin{array}{l}\text { Kareler } \\
\text { Ortalaması }\end{array}$ & F & p & $\begin{array}{l}\text { Anlamlı } \\
\text { Fark }\end{array}$ \\
& Gruplararası & 2.178 & 2 & 1.089 & 11.686 & .000 & A-B \\
& Toplam & 17.837 & 170 & & & & C-B \\
Araştırma Süreci & 15.659 & 168 & .093 & & & \\
& Gruplararası & 7.549 & 2 & 3.775 & 18.010 & .000 & A-B \\
& Gruplariçi & 35.211 & 168 & .210 & & & C-B \\
& Toplam & 42.760 & 170 & & & & \\
Bilgi Kullanımı & Gruplararası & 2.277 & 2 & 1.139 & 7.621 & .001 & C-B \\
& Gruplariçi & 25.101 & 168 & .149 & & & \\
& Toplam & 27.378 & 170 & & & & \\
Toplam & Gruplararası & 3.654 & 2 & 1.827 & 16.053 & .000 & A-B \\
& Gruplariçi & 19.120 & 168 & .114 & & & C-B \\
& Toplam & 22.774 & 170 & & & & \\
\hline p*.05, A: 0-2.5, B:2.51-3.00, C:3.01-4.00 & & & & & & \\
\hline
\end{tabular}

Tablo 12'de görüldüğü üzere Türkçe öğretmeni adaylarının akademik okuryazarlıklarının akademik başarı düzeyi değişkenine göre ölçeğin bütününde, akademik eğilim alt boyutunda ve araştırma süreci alt boyutunda anlamlı fark görülmüştür. Bu farkın hangi gruplar arasında kaynaklandığını ortaya çıkarmak amacıyla Tukey testi yapılmıştır. Tukey testine göre ölçeğin bütününde $\left[\mathrm{F}_{(2-168)}=16.053 ; \mathrm{p}<.05\right], 0-2.5$ puan $(\overline{\mathrm{X}}=4.77)$ ve $3.01-4.00$ puan $(\overline{\mathrm{X}}=4.75)$ akademik başarı ortalamasına sahip katılımcıların lehine 2.51-3.00 puan $(\bar{X}=4.44)$ akademik başarı ortalamasına sahip katılımcılara göre anlamlı bir fark görülmüştür. Tukey testine göre akademik eğilim alt boyutunda $\left[\mathrm{F}_{(2-168)}=11.686 ; \mathrm{p}<.05\right], 0-2.5$ puan $(\overline{\mathrm{X}}=4.75)$ ve 3.01-4.00 puan $(\bar{X}=4.77)$ akademik başarı ortalamasına sahip katılımcıların lehine 2.51-3.00 puan $(\bar{X}=4.52)$ akademik başarı ortalamasına sahip katılımcılara göre anlamlı bir fark görülmüştür. Tukey testine göre araştırma süreci alt boyutunda $\left[\mathrm{F}_{(2-168)}=18.010 ; \mathrm{p}<.05\right], 0-2.5$ puan $(\overline{\mathrm{X}}=4.84)$ ve 3.014.00 puan $(\bar{X}=4.73)$ akademik başarı ortalamasına sahip katılımcıların lehine 2.51-3.00 puan $(\bar{X}=4.29)$ akademik başarı ortalamasına sahip katılımcılara göre anlamlı bir fark görülmüştür. Tukey testine göre bilgi kullanımı alt boyutunda $\left[\mathrm{F}_{(2-168)}==7.621 ; \mathrm{p}<.05\right], 3.01-4.00$ puan $(\overline{\mathrm{X}}=4.74)$ akademik başarı ortalamasına sahip katılımcıların lehine 2.51-3.00 puan ( $\overline{\mathrm{X}}=4.48)$ akademik başarı ortalamasına sahip katılımcılara göre anlamlı bir fark görülmüştür.

Akademik başarı düzeyi açısından ölçeğin bütünü dikkate alındığında Türkçe öğretmeni adaylarının teknoloji yeterliliği öz-değerlendirmelerinin farklılaşıp farklılaşmadığını belirlemek amacıyla Tek yönlü ANOVA testi uygulanmıştır. Uygulanan testler sonucunda elde edilen sonuçlar Tablo 13' de gösterilmiştir. 
Türkçe Öğretmeni Adaylarının Akademik Okuryazarlık Düzeyleri ile Teknoloji Yeterliği Öz-Değerlendirmeleri Arasındaki İlişki

Tablo 13. Katılımcıların Teknoloji Yeterliliği Öz-Değerlendirmelerinin Akademik Başarı

Değişkenine Göre Tek Yönlü Anova Analiz Sonuçları

\begin{tabular}{llllllll}
\hline & $\begin{array}{l}\text { Varyansın } \\
\text { Kaynağı }\end{array}$ & $\begin{array}{l}\text { Kareler } \\
\text { Toplamı }\end{array}$ & sd & $\begin{array}{l}\text { Kareler } \\
\text { Ortalaması }\end{array}$ & F & p & $\begin{array}{l}\text { Anlamlı } \\
\text { Fark }\end{array}$ \\
\hline E-posta & Gruplararası & .008 & 2 & .004 & .058 & .943 & \\
& Gruplariçi & 11.658 & 168 & .069 & & & \\
& Toplam & 11.666 & 170 & & & & \\
Gwww & Gruplararası & .434 & 2 & .217 & 4.402 & .014 & A-B \\
& Gruplariçi & 8.288 & 168 & .049 & & & B-C \\
& Toplam & 8.722 & 170 & & & & \\
Entegre Uygulamalar & Gruplararası & 17.397 & 2 & 8.698 & 19.138 & .000 & A-B \\
& Gruplariçi & 76.358 & 168 & .455 & & & B-C \\
& Toplam & 93.755 & 170 & & & & \\
Teknolojiyle Öğretim & Gruplararası & 2.159 & 2 & 1.080 & 9.830 & .000 & A-B \\
& Gruplariçi & 18.449 & 168 & .110 & & & B-C \\
& Toplam & 20.609 & 170 & & & & \\
& Gruplararası & 1.333 & 2 & .666 & 11.347 & .000 & A-B \\
& Gruplariçi & 9.867 & 168 & .059 & & & B-C \\
& Toplam & 11.200 & 170 & & & & \\
\hline
\end{tabular}

$\mathrm{p}^{*}<.05, \mathrm{~A}: 0-2.5, \mathrm{~B}: 2.51-3.00, \mathrm{C}: 3.01-4.00$

Tablo 13'te görüldüğü üzere Türkçe öğretmeni adaylarının teknoloji yeterliliği özdeğerlendirmelerinin akademik başarı düzeyi değişkenine göre ölçeğin bütünü ve e-posta alt boyutu hariç diğer alt boyutlarda anlamlı fark görülmüştür. Bu farkın hangi gruplar arasında kaynaklandığını ortaya çıkarmak amacıyla Tukey testi yapılmıştır. Tukey testine göre ölçeğin bütününde $\left[\mathrm{F}_{(2-168)}=11.347, \mathrm{p}<.05\right], 0-2.5$ puan $(\overline{\mathrm{X}}=4.86)$ not ortalamasina sahip kat1lımcların lehine hem 2.51-3.00 puan ( $\bar{X}=4.55)$ akademik başarı ortalamasına sahip katılımcılara göre hem de 3.01-4.00 puan ( $\bar{X}=4.55)$ akademik başarı ortalamasına sahip katılımcılara göre anlamlı bir fark görülmüştür. Tukey testine göre www $\left[\mathrm{F}_{(2-168)}=4.402, \mathrm{p}<.05\right], 0-2.5$ puan $(\overline{\mathrm{X}}=4.89)$ not ortalamasına sahip katılımcıların lehine hem 2.51-3.00 puan $(\bar{X}=4.80)$ akademik başarı ortalamasına sahip katılımcılara göre hem de 3.01-4.00 puan ( $\bar{X}=4.81)$ akademik başarı ortalamasına sahip katılımcılara göre anlamlı bir fark görülmüştür. Tukey testine göre entegre uygulamalar $\left[\mathrm{F}_{(2-168)}=19.138, \mathrm{p}<.05\right], 0-2.5$ puan $(\overline{\mathrm{X}}=4.65)$ not ortalamasına sahip katılımcların lehine hem 2.51-3.00 puan ( $\overline{\mathrm{X}}=3.96)$ akademik başarı ortalamasına sahip katılımcılara göre hem de 3.01-4.00 puan ( $\bar{X}=3.57)$ akademik başarı ortalamasına sahip katılımcılara göre anlamlı bir fark görülmüştür. Tukey testine göre teknolojiyle öğretim $\left[\mathrm{F}_{(2-168)}=9.830, \mathrm{p}<.05\right], 0-2.5$ puan $(\bar{X}=4.92)$ not ortalamasına sahip katılımcıların lehine hem 2.51-3.00 puan $(\bar{X}=4.49)$ akademik başarı ortalamasına sahip katılımcılara göre hem de 3.01-4.00 puan $(\overline{\mathrm{X}}=4.60)$ akademik başarı ortalamasına sahip katılımcılara göre anlamlı bir fark görülmüştür.

Bir günde ortalama internette geçirilen süre değişkeni açısından ölçeğin bütünü ve alt boyutları dikkate alındığında Türkçe öğretmeni adaylarının internet tabanlı okuma 
motivasyonu ve etkileşimlerine yönelik algı düzeylerinin farklılaşıp farklılaşmadığını belirlemek amacıyla Tek yönlü ANOVA testi uygulanmıştır. Uygulanan testler sonucunda elde edilen sonuçlar Tablo 16' de gösterilmiştir.

Tablo 14. Katılımcıların Akademik Okuryazarlık Düzeylerinin Bir Günde Ortalama

İnternette Geçirilen Süre Değişkenine Göre Tek Yönlü Anova Analiz Sonuçları

\begin{tabular}{llllllll}
\hline & $\begin{array}{l}\text { Varyansın } \\
\text { Kaynağı }\end{array}$ & $\begin{array}{l}\text { Kareler } \\
\text { Toplamı }\end{array}$ & sd & $\begin{array}{l}\text { Kareler } \\
\text { Ortalaması }\end{array}$ & F & p & $\begin{array}{l}\text { Anlamlı } \\
\text { Fark }\end{array}$ \\
\hline Akademik Eğilim & Gruplararası & 3.611 & 3 & 1.204 & 14.127 & .000 & C-B \\
& Gruplariçi & 14.227 & 167 & .085 & & & C-D \\
& Toplam & 17.837 & 170 & & & & \\
Araştırma Süreci & Gruplararası & 11.826 & 3 & 3.942 & 21.282 & .000 & C-B \\
& Gruplariçi & 30.934 & 167 & .185 & & & D-B \\
& Toplam & 42.760 & 170 & & & & \\
Bilgi Kullanımı & Gruplararası & 5.993 & 3 & 1.978 & \multirow{2}{*}{15.402} & .000 & C-B \\
& Gruplariçi & 21.445 & 167 & .128 & & & C-D \\
& Toplam & 27.378 & 170 & & & & \\
\cline { 3 - 3 } Toplam & Gruplararası & 6.081 & 3 & 2.027 & 20.278 & .000 & C-B \\
& Gruplariçi & 16.693 & 167 & .100 & & & D-B \\
& Toplam & 22.774 & 170 & & & & \\
\hline
\end{tabular}

$\mathrm{p}^{*}<.05$, A: 0-1 saat, B: 2-3 saat, C: 4-6 saat, D: 7 saat ve üzeri

Tablo 14'te görüldüğü üzere Türkçe öğretmeni adaylarının akademik okuryazarlık düzeylerinin bir günde ortalama internette geçirilen süre değişkenine göre ölçeğin bütünü ve tüm alt boyutlarında anlamlı fark görülmüştür. Bu farkın hangi gruplar arasında kaynaklandığını ortaya çıkarmak amacıyla Tukey testi yapılmıştır. Tukey testine göre ölçeğin bütününde $\left[\mathrm{F}_{(3-167)}=20.278 ; \mathrm{p}<.05\right]$, hem günde 4-6 saat $(\overline{\mathrm{X}}=4.81)$ internete girenlerin lehine 2-3 saat ( $\bar{X}=4.37)$ internette zaman geçirenler arasında hem de 7 saat ve üzeri $(\bar{X}=4.63)$ internete girenlerin lehine 2-3 saat $(\overline{\mathrm{X}}=4.37)$ internette zaman geçirenler arasında anlamlı fark görülmüştür. Tukey testine göre akademik eğilim alt boyutunda $\left[F_{(3-167)}=14.127 ; p<.05\right]$, günde 4-6 saat $(\bar{X}=4.82)$ internete girenlerin lehine hem 2-3 saat $(\bar{X}=4.49)$ internette zaman geçirenler ile arasında hem de 7 saat ve üzeri $(\bar{X}=4.60)$ internette zaman geçirenler ile arasında anlamlı fark görülmüştür. Tukey testine göre araştırma süreci alt boyutunda $\left[\mathrm{F}_{(3-167)}=21.282 ; \mathrm{p}<.05\right]$, hem günde 4-6 saat $(\bar{X}=4.78)$ internete girenlerin lehine 2-3 saat $(\bar{X}=4.19)$ internette zaman geçirenler arasında hem de 7 saat ve üzeri $(\bar{X}=4.73)$ internete girenlerin lehine $2-3$ saat $(\bar{X}=4.19)$ internette zaman geçirenler arasında anlamlı fark görülmüştür. Tukey testine göre bilgi kullanımı alt boyutunda $\left[\mathrm{F}_{(3-167)}=15.402 ; \mathrm{p}<.05\right]$, günde 4-6 saat $(\overline{\mathrm{X}}=4.82)$ internete girenlerin lehine hem 2-3 saat $(\bar{X}=4.40)$ internette zaman geçirenler ile arasında hem de 7 saat ve üzeri $(\bar{X}=4.53)$ internette zaman geçirenler ile arasında anlamlı fark görülmüştür.

Bir günde ortalama internette geçirilen süre değişkeni açısından ölçeğin bütünü dikkate alındığında Türkçe öğretmeni adaylarının teknoloji yeterliliği öz-değerlendirmelerinin 
Türkçe Öğretmeni Adaylarının Akademik Okuryazarlık Düzeyleri ile Teknoloji Yeterliği Öz-Değerlendirmeleri Arasındaki İlişki

farklılaşıp farklılaşmadığını belirlemek amacıyla Tek yönlü ANOVA testi uygulanmıştır. Uygulanan testler sonucunda elde edilen sonuçlar Tablo 15' de gösterilmiştir.

Tablo 15. Katılımcıların Teknoloji Yeterliliği Öz-Değerlendirmelerinin Bir Günde Ortalama İnternette Geçirilen Süre Değişkenine Göre Tek Yönlü Anova Analiz Sonuçları

\begin{tabular}{|c|c|c|c|c|c|c|c|}
\hline & $\begin{array}{l}\text { Varyansın } \\
\text { Kaynağ1 }\end{array}$ & $\begin{array}{l}\text { Kareler } \\
\text { Toplamı }\end{array}$ & sd & $\begin{array}{l}\text { Kareler } \\
\text { Ortalaması }\end{array}$ & $F$ & $\mathrm{p}$ & $\begin{array}{l}\text { Anlamlı } \\
\text { Fark }\end{array}$ \\
\hline \multirow[t]{3}{*}{ E-posta } & Gruplararası & 1.145 & 3 & .382 & 6.057 & $.001^{*}$ & C-B \\
\hline & Gruplariçi & 10.522 & 167 & .063 & & & C-D \\
\hline & Toplam & 11.666 & 170 & & & & \\
\hline \multirow[t]{3}{*}{ www } & Gruplararası & 1.720 & 3 & .573 & 13.678 & $.000^{*}$ & C-B \\
\hline & Gruplariçi & 7.001 & 167 & .042 & & & C-D \\
\hline & Toplam & 8.722 & 170 & & & & \\
\hline \multirow{3}{*}{$\begin{array}{l}\text { Entegre } \\
\text { Uygulamalar }\end{array}$} & Gruplararası & 17.266 & 3 & 5.755 & 12.566 & $.000^{*}$ & D-C \\
\hline & Gruplariçi & 76.489 & 167 & .458 & & & $\mathrm{~B}-\mathrm{C}$ \\
\hline & Toplam & 93.755 & 170 & & & & \\
\hline \multirow{3}{*}{$\begin{array}{l}\text { Teknolojiyle } \\
\text { Öğretim }\end{array}$} & Gruplararası & 1.462 & 3 & .487 & 4.251 & $.006^{*}$ & C-B \\
\hline & Gruplariçi & 19.147 & 167 & .115 & & & \\
\hline & Toplam & 20.609 & 170 & & & & \\
\hline \multirow[t]{3}{*}{ Toplam } & Gruplararası & .376 & 3 & .125 & 1.935 & .126 & \\
\hline & Gruplariçi & 10.824 & 167 & .065 & & & \\
\hline & Toplam & 11.200 & 170 & & & & \\
\hline
\end{tabular}

$\mathrm{p}^{*}<.05$, A: 0-1 saat, B: 2-3 saat, C: 4-6 saat, D: 7 saat ve üzeri

Tablo 15'de görüldügü üzere Türkçe öğretmeni adaylarının teknoloji yeterliliği özdeğerlendirmelerinin bir günde internette geçirdikleri zaman değişkenine göre ölçeğin bütününde anlamlı bir fark göstermemektedir $\left[\mathrm{F}_{(3-167)}=1.935, \mathrm{p}>.05\right]$. Bununla beraber ölçeğin tüm alt boyutlarındaysa anlamlı fark görülmüştür. Bu farkın hangi gruplar arasında kaynaklandığını ortaya çıkarmak amacıyla Tukey testi yapılmıştır. Tukey testine göre e-posta alt boyutunda $\left[\mathrm{F}_{(3-167)}=6.057, \mathrm{p}<.05\right]$, günde $4-6$ saat $(\overline{\mathrm{X}}=4.94)$ internette zaman geçirenlerin lehine hem 2-3 saat $(\bar{X}=4.77)$ internette zaman geçirenler arasında hem de 7 saat ve üzeri $(\bar{X}=4.78)$ internette zaman geçirenler arasında anlamlı fark görülmüştür. Tukey testine göre www alt boyutunda $\left[\mathrm{F}_{(3-167)}=13.678, \mathrm{p}<.05\right]$ günde 4-6 saat $(\bar{X}=4.96)$ internette zaman geçirenlerin lehine hem $2-3$ saat $(\bar{X}=4.75)$ internette zaman geçirenler arasında hem de 7 saat ve üzeri $(\bar{X}=4.86)$ internette zaman geçirenler arasında anlamlı fark görülmüştür. Tukey testine göre entegre uygulamalar alt boyutunda $\left[\mathrm{F}_{(3-167)}=12.566, \mathrm{p}<.05\right]$, hem 7 saat ve üzeri $(\overline{\mathrm{X}}=4.32)$ internette zaman geçirenlerin lehine $4-6$ saat $(\bar{X}=4.51)$ internette zaman geçirenler arasında hem de 2-3 saat ( $\bar{X}=4.00)$ internette zaman geçirenlerin lehine $4-6$ saat $(\bar{X}=4.51)$ internette zaman geçirenler arasında anlamlı fark görülmüştür. Tukey testine göre teknolojiyle öğretim boyutunda $\left[\mathrm{F}_{(3-167)}=4.251, \mathrm{p}<.05\right], 4-6$ saat $(\overline{\mathrm{X}}=4.66)$ internette zaman geçirenlerin lehine $2-3$ saat $(\bar{X}=4.46)$ internette zaman geçirenler arasında anlamlı fark görülmüştür. 
Tablo 16. Katılımcıların Akademik Okuryazarlık Düzeyleri ile Teknoloji Yeterliği

Arasındaki İlişkiye Yönelik Pearson Korelasyon Analizi

\begin{tabular}{llll}
\hline & Yazma & Okuma \\
\hline Yazma & Pearson Correlation & 1 & $.517^{* *}$ \\
& Sig. (2-tailed) & & $.000^{*}$ \\
& $\mathrm{~N}$ & 171 & 171 \\
Okuma & Pearson Correlation & $.517^{* *}$ & 1 \\
& Sig. (2-tailed) & $.000^{*}$ & \\
& $\mathrm{~N}$ & 171 & 171 \\
\hline
\end{tabular}

${ }^{*} \mathrm{p}<.01$ düzeyinde anlamlı fark vardır.

Tablo 16'da görüldüğü üzere Türkçe eğitimi öğretmen adaylarının akademik okuryazarlık düzeyleri ile teknoloji yeterliği arasında orta düzeyde, pozitif ve anlamlı bir ilişki olduğu görülmektedir [r=0.517, p<.01]. Buna göre öğretmen adaylarının akademik okuryazarlık düzeyleri arttıkça teknoloji yeterliği öz-değerlendirmelerinin de arttığ söylenebilir. Determinasyon katsayısı $\left[\mathrm{r}^{2}=.27\right]$ dikkate alındığında akademik okuryazarlık düzeyleri ölçeğindeki toplam varyansın \%27'sinin 21. Yüzyıl Öğrenmelerinde Teknoloji Yeterliliği Özdeğerlendirme ölçeğinden kaynaklandığ 1 söylenebilir.

\section{Tartışma, Sonuç ve Öneriler}

$\mathrm{Bu}$ araştırmada Türkçe öğretmeni adaylarının dijital yazma tutumları ile dijital okuma eğilimleri arasındaki ilişki belirlenmeye çalışılmıştır. Araştırmaya Çanakkale Onsekiz Mart Üniversitesi'nde öğrenim gören 171 öğretmen adayı katılmıştır. Katılımcıların \%78.9'unu kadın, \% 21,1'ini erkek öğretmen adayları oluşturmaktadır. Ayrıca \%18.7'sinin birinci sınıf, \%20.5'inin ikinci sınıf, \%26.3'ünün üçüncü sınıf, \%34.5'inin ise dördüncü sınıf öğrencileri oluşturmaktadır. Katılımcların \%6.6'sının 0-2.5 puan arası, \%34.5'inin 2.51-3.00 puan arası ve \%58.9'unun 3.01-4.0 puan arası akademik başarı puanına sahip olduğu belirlenmiştir. Katılımcların bir günde ortalama \%5.8'inin 0-1 saat, \%28.7'sinin 2-3 saat, \%53.8' inin 4-6 saat, $\% 11.7$ 'sinin ise yedi veya yedi saatin üzerinde internette vakit geçirdikleri tespit edilmiştir.

Türkçe eğitimi öğretmen adaylarının akademik okuryazarlık düzeyleri ile teknoloji yeterliği arasında orta düzeyde, pozitif ve anlamlı bir ilişki olduğu belirlenmiştir. Korelasyonun orta düzeyde olması aralarında ilişki olduğunu göstermektedir. Birindeki değişim diğerini de orta düzeyde etkilemektedir. Buna göre öğretmen adaylarının akademik okuryazarlık düzeyleri ile teknoloji yeterliklerinin birbirlerini olumlu yönde etkilediği söylenebilir.

Türkçe öğretmeni adaylarının akademik okuryazarlık düzeylerinin yüksek seviyede olduğu sonucuna ulaşılmıştır. Türkçe öğretmenliği programlarında ikinci yarı yılda verilen "Türk Dili 2" dersi içerik olarak akademik okuryazarlığı beslediği ve araştırmanın bu sonucu ile eşleştiği düşünülebilir. Bununla beraber doğrudan Türkçe öğretmeni adayları ile ilgili akademik okuryazarlık üzerine araştırmaya rastlanmamıştır. Ancak literatürde akademik okuryazarlık kavramının kapsamı içinde olan akademik özyeterlik, akademik veya bilimsel dil becerileri (bilimsel yazma, akademik dinleme vb.) ile ilgili birçok çalışma mevcuttur (Aydın, 2010; Bayat, 2014; Ekmekçi, 2018; Güneş, 2019; Halitoğlu, 2018; Kurudayığlu ve Çimen, 2020; Lent, Brown 
ve Larkin, 1986). Araştırmanın bulgularından hareketle araştırmaya katılan Türkçe öğretmeni adaylarında erkek adayların akademik okuryazarlık algılarının kadınlara göre daha yüksek düzeyde olduğu sonucuna ulaşılmıştır. Bununla beraber bilgi kullanımı ve akademik eğilim alt boyutlarında da Türkçe öğretmeni adaylarında erkek adayların akademik okuryazarlık algılarının kadınlara göre daha yüksek düzeyde olduğu sonucuna ulaşılmıştır. Ayrıca katılımcıların araştırma süreci alt boyutunda ise akademik okuryazarlık algılarının cinsiyet değişkenine göre anlamlı bir farklılık görülmemiştir. Türkçe öğretmeni adaylarının akademik okuryazarlık algısının sınıf düzeyi değişkenine göre değişmediği sonucuna ulaşılmıştır. Bu sonucun "Türk Dili 2" dersinin etkisinden kaynaklandığı düşünülebilir. Birinci sinıftan itibaren akademik okuryazarlık farkındalığının söz konusu bu dersle geliştiği veya desteklendiği düşünülebilir. Katılımcılardan elde edilen bulgulardan hareketle akademik okuryazarlık düzeyi akademik başarı değişkenine göre anlamlı bir fark görülmüştür. Akademik başarı seviyesi arttıkça akademik başarı düzeyinin arttığı sonucuna ulaşılmıştır. Araştırmanın bulgularına göre katılımcıların akademik okuryazarlık düzeylerinin bir günde ortalama internette geçirdikleri süre değişkenine göre anlamlı farklılık görülmüştür. Türkçe öğretmen adaylarının günde ortalama 4-6 süre geçirenlerinin günde ortalama hem 2-3 saat geçirenler hem de yedi ve üzeri saat süre interneti kullananlara göre akademik okuryazarlık algılarının daha yüksek düzeyde olduğu sonucuna ulaşılmıştır.

Türkçe öğretmeni adaylarının teknoloji yeterliliği algılarının yüksek düzeyde olduğu sonucuna ulaşılmıştır. Ancak araştırmanın bulgularına göre ölçme aracının bütünü ve diğer alt boyutlarında Türkçe öğretmen adaylarının teknoloji yeterliliği algılarının "kesinlikle katılıyorum" düzeyinde iken entegre uygulamalar boyutunda ise "katılıyorum" düzeyinde algıya sahip oldukları sonucuna ulaşılmıştır. Ölçeğin bütünü için Erdin'in (2021) ve İncel'in (2021) çalışmalarında da teknoloji kullanım yeterlilikleri yüksek düzeyde bulunmuştur. Bu araştırmanın sonucu ile Erdin ve İncel'in çalışmaları örtüşmektedir.

Türkçe öğretmeni adaylarının 21. Yüzyıl Öğrenmelerinde Teknoloji Yeterliliği Özdeğerlendirme ölçeğinin bütünü dikkate alındığında cinsiyet değişkeni açısından anlamlı bir fark görülmemiştir. Bununla beraber e-posta ve www alt boyutlarında erkek adayların, entegre uygulamalar alt boyutunda ise kadın adayların lehine anlamlı bir fark görülmüştür. Erdin'in (2021) çalışmasındaki cinsiyet değişkenin teknoloji yeterliliğini etkilemediği sonucuyla ile eşleşirken İncel'in (2021) çalışmasında teknoloji yeterliliğinin erkeklerin lehine farklılık sonucuna ulaşılmıştır. Türkçe öğretmeni adaylarının teknoloji yeterliliği özdeğerlendirmelerinin sınıf düzeyi değişkenine göre anlamlı farklılık göstermemektedir. Ancak sadece entegre uygulamalar alt boyutunda Türkçe öğretmeni adaylarının teknoloji yeterliliği öz-değerlendirmelerinin sınıf düzeyi değişkeni açısından 1.sınıflara göre 4 . sınıfların lehine anlamlı bir fark görülmüştür. Türkçe öğretmeni adaylarının teknoloji yeterliliği öz-değerlendirmelerinin akademik başarı düzeyi değişkenine göre ölçeğin bütünü ile www, Entegre Uygulamalar ve Teknolojiyle Öğretim alt boyutlarında akademik başarı değişkenine göre anlamlı bir fark görülmüştür. Araştırmanın bulgularından hareketle ölçeğin bütünü ile www, Entegre Uygulamalar ve Teknolojiyle Öğretim alt boyutlarında 0-2.5 puan not ortalamasına sahip Türkçe öğretmeni adaylarının hem 2.51-3.00 puan hem de 3.01-4.00 puan not ortalamasına sahip katılımcılara göre teknoloji yeterliliği algılarının daha yüksek düzeyde olduğu sonucuna ulaşılmıştır. Türkçe öğretmeni adaylarının teknoloji yeterliliği özdeğerlendirmelerinin bir günde internette geçirdikleri zaman değişkenine göre ölçeğin bütününde anlamlı bir fark göstermemektedir. Ancak tüm alt boyutlarda katılımcıların teknoloji yeterliliği öz-değerlendirmelerinin bir günde internette geçirdikleri zaman 
değişkenine göre anlamlı fark görülmüştür. Türkçe öğretmeni adaylarının teknoloji yeterliliği öz-değerlendirmelerinin E-posta, www, entegre uygulamalar ve teknolojiyle öğretim alt boyutlarında bir günde internette geçirdikleri zaman değişkenine göre anlamlı bir farklılık görülmüştür. E-posta ve www alt boyutlarında günde ortalama 4-6 saat süresince internette zaman geçirenlerin lehine günde ortalama hem 2-3 saat hem de yedi ve üzeri saat süre interneti kullananlara göre teknoloji yeterliliği algılarının daha yüksek düzeyde olduğu sonucuna ulaşılmıştır. Entegre uygulamalar alt boyutunda günde ortalama hem 7 saat ve üzeri internette zaman geçirenlerin lehine hem de 2-3 saat internette zaman geçirenlerin lehine 4-6 saat internette zaman geçirenlere göre teknoloji yeterliliği algılarının daha yüksek düzeyde olduğu sonucuna ulaşılmıştır. Teknolojiyle öğretim alt boyutunda günde ortalama 4-6 saat internette zaman geçirenlerin lehine 2-3 saat internette zaman geçirenlere göre teknoloji yeterliliği algılarının daha yüksek düzeyde olduğu sonucuna ulaşılmıştır. Ölçeğin bütünü için Erdin'in (2021) çalışmasında da teknolojik araçlar kullanıldıkça teknoloji yeterliliklerinin olumlu yönde etkilendiği ve daha yüksek düzeyde algılandığı bulunmuştur.

Bu çalışmada Türkçe öğretmeni adaylarının akademik okuryazarlık düzeyleri ile teknoloji yeterliği öz-değerlendirmeleri arasındaki ilişkiyi belirlemek amaçlanmıştır. Bu amaç doğrultusunda ulaşılan sonuçlar ve bu sonuçlar doğrultusunda sunulan öneriler aşağıdaki gibidir:

- Akademik okuryazarlığın farkındalığının oluşması özellikle ana dili öğretiminin desteği ile özelde akademik başarıyı genelde ise ülke kalkınmasını önemli yönde destekleyecektir. Akademik yazma ve okumanın gelişmesi doğrudan öğretmen ve öğretmen adaylarında özgüveni geliştirip ve akademik özyeterliği destekleyecektir. Lent ve diğerine (1986) göre akademik özyeterlik ile akademik başarı arasında doğrusal bir ilişki vardır. Aynı durum akademik güdülenme ile akademik özyeterlik arasında da yüksek düzey bir ilişki tespit edilmiştir (Akbay ve Gizir, 2010; Aydın, 2010). Bu bağlamda Türkçe öğretmenliği programlarında verilen “Türk Dili 2" dersinin birinci yılda veriliyor olması doğru bir uygulamadır. Ancak elde edilen veriler sonucunda Türkçe öğretmeni adaylarının araştırma süreçlerinde desteklemesi için daha çok ürün üretecek uygulamalara yönlendirilmesi tavsiye edilebilir. Bununla beraber sözü edilen ders kapsamında veya lisans programı bitiminde öğrencilerden bitirme tezi gibi bir ürün istenmesi hem akademik okuryazarlık farkındalığını pekiştireceği hem de yarınlar için büyük ölçekte ülke refahını olumlu yönde destekleyeceği düşünülmektedir.

- Yurtdışı kaynaklardan akademik okuryazarlık ölçeklerinin Türk kültürüne uyarlamaları yapılabileceği gibi doğrudan bu konuda ölçme araçlarının sayısının arttırılması için çalışmalarında faydası olacağı aşikardır. Böylelikle akademik okuryazarlığı etkileyen değişkenler ve algılar daha geniş kapsamda araştırılıp değerlendirilebilir.

- İnternette daha uzun veya daha kısa süre zaman geçirmenin akademik okuryazarlık ve teknoloji yeterliliği ile ilişkisinin anlaşılabilmesi için daha derinlemesine yarı yapılandırılmış formlarla nitel araştırmaların desteğine ihtiyaç vardır. Katılımcıların internet araçları ve medya kaynakları ile ilgili durumları incelenerek akademik okuryazarlıkla ilişkisi aydınlatılması alana katkı sağlayacaktır.

- Teknoloji yeterliliğini güçlendirmek için güncel teknolojiler kullanılarak ürünler üretilmesi teşvik edilebilir. Hesap tabloları ile grafik oluşturabilme, grafik kullanarak medya ürünü oluşturabilme, kelime işlemci programlarındaki hakimiyet ile ellerinde var 
olan bilgi ve metinlerle bir veri tabanı oluşturabilme yetisinin hem sahada görevli öğretmenler için hizmet içi eğitimlerle hem de lisans öğretiminde "öğretim teknolojileri" dersinde desteklenebilir.

\section{Kaynakça}

Akbay, S., ve Gizir, C. (2010). Cinsiyete göre üniversite öğrencilerinde akademik erteleme davranışı: akademik güdülenme, akademik özyeterlik ve akademik yükleme stillerinin rolü. Mersin Üniversitesi Eğitim Fakültesi Dergisi, 6(1), 60-78.

Akkaya, A., ve Toprak, F. (2020) Görsel okuryazarlık karikatürlerle Türkçe dersi işleme süreci. Elazığ:Asos yayıncılık

Arcagök, S. (2020). Öğretmenlerin dijital vatandaşlığa yönelik algılarının incelenmesi. Yüzüncü Yıl Üniversitesi Ĕ̆itim Fakültesi Dergisi, 17(1), 534-556.

Aydın, F. (2010). Akademik başarının yordayıcısı olarak akademik güdülenme, özyeterlik ve sınav kaygısı. Yayımlanmamış Yüksek Lisans Tezi. Hacettepe Üniversitesi, Sosyal Bilimler Enstitüsü, Ankara.

Baş, B., ve Yıldırım, T. (2018). Yabancılara Türkçe öğretiminde teknoloji entegrasyonu. Ana Dili Ĕ̈itimi Dergisi 6(3), 827 - 839.

Bayat, N. (2014). Öğretmen adaylarının eleştirel düşünme düzeyleri ile akademik yazma başarıları arasındaki ilişki. Eğitim ve Bilim, 39(173).

Branscomb, A. W. (1981). Knowing how to know. Science, Technology \& Human Values, 6(36), 5- 9.

Büyüköztürk, Ş., Çakmak, E., Akgün, Ö. E., Karadeniz, Ş., ve Demirel, F. (2018). Eğitimde bilimsel araştırma yöntemleri. Ankara: Pegem akademi.

Christensen, R., ve Knezek, G. (2017). Validating the technology proficiency self-assessment questionnaire for 21st century learning (TPSA C-21). Journal of Digital Learning in Teacher Education, 33(1), 20-31.

Demir, S. ve Deniz, H. (2020). Akademik okuryazarlık ölçeği'nin geliştirilmesi: geçerlik ve güvenirlik çalışması. Kastamonu Education Journal, 28(3), 1366-1379.

Doru, M. N. (2018). Akademik okuryazalık. M. Öztürk (Ed.) Sosyal bilimlerde etik sorunlar içinde.. Ankara: Nobel.

Ekmekçi, V. (2018) Akademik Türkçenin yabancı dil olarak öğretimi süreci içerisinde dinleme öğrenme alanına yönelik bir eylem araştırması. Aydın Tömer Dil Dergisi, 3(1), 21-46.

Elkıran, Y.M. (2017). Türkçe Öğretmeni Adaylarının Bilgi ve İletişim Teknolojilerini Kullanımlarının İncelenmesi. International Journal of Innovative Approaches in Education, 1(1), 4558.

Elmborg, J. (2006). Critical information literacy: Implications for instructional practice. The Journal of Academic Librarianship, 32(2). 117-220.

Erdin, Y. (2021). Factors affecting perceived technology proficiency of Turkish teachers of English in the light of 21st century learning Yayımlanmamış Yüksek Lisans Tezi. Bursa Uludağ Üniversitesi, Eğitim Bilimleri Enstitüsü, Bursa. 
Fidan, M., Debbağ, M. ve Çukurbaşı, B. (2020). Technology proficiency self-assessments of teachers becoming professional in the 21st century: A scale adaptation study. Pegem Eğitim ve Öğretim Dergisi, 10(2), 465-492.

Geçgel, H., Kana, F., Öztürk, N. E., ve Akkaş, İ. (2020). Öğretmen adaylarının okuma motivasyonları ve sosyal medyaya özgü epistemolojik inançları arasındaki ilişkinin incelenmesi. Dil Eğitimi ve Araştırmaları Dergisi, 6(2), 478-507.

George, D., ve Mallery, P. (2010). SPSS for Windows step by step. A simple study guide and reference (10. Baskl). GEN, Boston, MA: Pearson Education, Inc.

Güneş, F. (2019). Okuryazarlık yaklaşımları. Sınırsız Ĕ̆itim ve Araştırma Dergisi, 4(3), 224-246.

Güzel, A., ve Karadağ, Ö. (2013). Anlatma becerileri açısından “Türkçe Dersi Öğretim Programı (6, 7, 8. Sınıflar)" na eleştirel bir bakış. Ana Dili Eğitimi Dergisi, 1(1), 45-52.

Halitoğlu, V. (2018). Türkçenin yabancı dil olarak öğretiminde akademik dinleme becerisinin geliştirilmesine yönelik bir eylem araştırması. Aydın TÖMER Dil Dergisi, 21.

İncel, C. (2021). Okul yöneticilerinin teknoloji kullanım yeterliğine ilişkin algıları. Yayımlanmamış Tezsiz Yüksek Lisans Tezi. Pamukkale Üniversitesi, Eğitim Bilimleri Enstitüsü, Denizli.

Karasar, N. (2007). Bilimsel araştırma yöntemi. Ankara:Nobel yayın dağıtım.

Karatay, H. (2011). 4+1 planlı yazma ve değerlendirme modelinin öğretmen adaylarının yazılı anlatım tutumlarını ve yazma becerilerini geliştirmeye etkisi. Turkish Studies - International Periodical for the Languages, Literature and History of Turkish or Turkic, 6(3), 1029-1047.

Kurudayığlu, M., ve Çimen, L. (2020). Yabancı dil olarak Türkçe öğrenen öğrencilerin akademik yazılarında etkileşimli üstsöylem belirleyicilerinin kullanımı. OPUS Uluslararası Toplum Araştırmaları Dergisi, 16(31), 3899-3923.

Lent, R. W., Brown, S. D., ve Larkin, K.C. (1986). Self-efficacy in the prediction of academic performance and perceived career options. Journal of Counseling Psychology, 33, 265-269.

Miller, J. D. (1983). Scientific literacy: A conceptual and empirical review. Daedalus, 29-48.

Özbay, M., ve Özdemir, O. (2014). Türkçe öğretim programı için bir öneri:dijital okuryazarlığa yönelik amaç ve kazanımlar. Okuma Yazma Ĕ̆itimi Araştırmaları, 2(2), 31-40.

TDK, (2021) https://sozluk.gov.tr/ erişim tarihi:20.03.2021

Temizyürek, F., ve Balcı, A. (2015). Cumhuriyet dönemi ilköğretim okulları türkçe programları. Ankara: Nobel Yayıncilik

UN, (2015) General Assembly Resolution A/RES/70/1. Transforming Our World, the 2030 Agenda for Sustainable Development. internet adresi: http://www.un.org/ga/search/view_doc.asp?symbol=A/RES/70/1\&Lang=E. (erişim tarihi:27.03.2021).

UNESCO, (2021) Literacy internet adresi: https://en.unesco.org/themes/literacy erişim tarihi:27.03.2021

UNESCO. (1968). Literacy: 1965-1967, Paris:UNESCO.

Ustabulut, M. Y. (2021). Türkçe öğretmeni adaylarının yaşam becerileri ile ilgili görüşlerinin çeşitli değişkenler açısından incelenmesi. Kahramanmaraş Sütçü İmam Üniversitesi Sosyal Bilimler Dergisi, 18 (1) , 205-219. 